\title{
$\mathrm{Al}_{2} \mathrm{O}_{3}-\mathrm{Mg}$ 系粉末パック法による鋼材表面への 低 $\mathrm{Al}$ 合金層の形成
}

\author{
平井伸治* 片山 博* 蟹澤秀雄** \\ *室蘭工業大学工学部材料物性工学科 \\ **新日本製鐵株式会社技術開発本部室蘭技術研究部
}

J. Japan Inst. Metals, Vol. 58, No. 12 (1994), pp. 1408-1413

\section{Formation of Low Al Layer on Steel Surface by Powder Packing Method Using Mixture of $\mathrm{Al}_{2} \mathrm{O}_{3}$ and $\mathrm{Mg}$ Powders}

\author{
Shinji Hirai*, Hiroshi G. Katayama* and Hideo Kanisawa** \\ *Department of Materials Science and Engineering, Faculty of Engineering, Muroran Institute of Technology, \\ Muroran \\ **Muroran R\&D Lab. Technical Development Bureau, Nippon Steel Co. Ltd., Muroran
}

\begin{abstract}
In order to inprove the corrosion resistance to chloride-containing aqueous solution of steel for concrete reinforcement, an attempt were made to form a low $\mathrm{Al}$ alloyed layer on steel surface by the powder packing method using a mixture of $\mathrm{Al}_{2} \mathrm{O}_{3}$ and $\mathrm{Mg}$ powders. The surface $\mathrm{Al}$ concentration and the thickness of alloyed layer increased with the increase of the treating temperature and time and $\mathrm{Mg}$ content in the powder mixture. In the case of the powder mixture containing $\mathrm{SiO}_{2}$, the surface $\mathrm{AI}$ concentration and the thickness of the alloyed layer decreased with the increase of $\mathrm{SiO}_{2}$ content. On the other hand, the surface $\mathrm{Si}$ concentration increased with $\mathrm{SiO}_{2}$ content up to 5 mass $\% \mathrm{SiO}_{2}$ and then decreased. The anodic polarization tests showed a corrosion potential of $-430 \mathrm{mV}$, a current density for maintaining the passive state of approximately $7 \mu \mathrm{A} \cdot \mathrm{cm}^{-2}$, and a pitting potential of $+600 \mathrm{mV}$ for the specimen having the surface composition of about 10 mass $\% \mathrm{Al}$. The corrosion potential increased and the pitting potential declined when the surface $\mathrm{Al}$ concentration was increased or decreased. In the case of a low AI-Si alloyed layer containing 4.8 mass $\% \mathrm{Al}$ and $1.8 \mathrm{mass} \% \mathrm{Si}$, the pitting potential was almost the same as that of the low-Al alloyed layer, but the current density for maintaining the passive state was remarkably lower. In tensile and bending tests, it was found that an alloyed layer having the surface composition of about 10 mass\%Al did not degrade the mechanical properties of the parent material and that it had excellent adhesion with the parent material. An alloyed layer could be formed even by heating specimen in no contact with the powder mixture. From this fact, it is concluded that $\mathrm{Al}_{2} \mathrm{O}$ and $\mathrm{SiO}$ vapors produced in the powder mixture is reduced by $\mathrm{Mg}$ vapor on the surface of the specimen, forming the alloyed layer.
\end{abstract}

(Received June 17, 1994)

Keywords: low aluminum alloyed layer, steel, powder packing method, $\mathrm{Al}_{2} \mathrm{O}_{3}$, magnesium

\section{I，緒言}

近年, 酸性雨によるコンクリートの中性化，コンクリートヘ の未洗浄の海砂の使用, 海浜地区にお忷る風雨によるコンクリ 一ト構造物への塩粒子の蓄積, 寒冷地に括㚈る塩類等の路面凍 結防止剤の散布等により、コンクリート構造物の塩害劣化が問 題となっている(1). その原因は, 通常の強アルカリ性環境下で は腐食しない鉄筋用棒鋼が，アルカリ性を失ったコンクリート 中では，水と酸素による腐食を受けやすくなり，ぬた強アルカ リ性であって子塩素イオンの共存により腐食が促進されるため である(2)(3).

ところで, Sykes と Bampfylde ${ }^{(4)}$ は Al 0.83〜16.16 mass\% 含有する数種の $\mathrm{A} 1$ 鋼の耐海水性を塩水噴霧試験により調べた
ところ $\mathrm{Al}$ 含有量の增加とともに耐塩性は堌加し，とくに $\mathrm{Al}$ を $10 \mathrm{mass} \%$ 以上含有する $\mathrm{Al}$ 鋼は著しい耐塩性を有すること を最初に明らか火した，最近では，この種の $\mathrm{Al}$ 鋼は，高濃度 の塩素イオンを含む中性就よび強アルカリ性水溶液中に拁いて む優れた耐盐性を有することが報告されている(5)、しかし，通 常の溶解法で製造した $\mathrm{Al}$ 鍼は，Al 含有量の增加とともに非金 属介在物の析出により脆化し，伸びや衝撃值が著しく低いこと が知られている(4)，そこで，鉄筋用棒銅としては，表面処理に より表面以 $\mathrm{Al}$ 在 8～16 mass\%舍有する低 $\mathrm{Al}$ 合金層老形成さ 世方が有利と考光られる。

従来からの溶融 $\mathrm{A} 1$ ×ッキ材は, 耐候性之而海水性 ${ }^{(6)-(9)}$ さら に耐高温酸化性 ${ }^{(10)}$ には優れるが，メッ平層が $\mathrm{Fe}_{2} \mathrm{Al}_{5}$ を主体と する高 $\mathrm{AI}$ 濃度の合金層とメッキ浴の付着層から構成されるた め，高アルカリ性の環境下炕括ける耐塩性は期待でさない－ 
方, カロライジング法で知られる粉末パック法による $\mathrm{Al}$ 拡散 被覆も, 鋼の耐高温酸化性の向上を目的に, 表面に $\mathrm{Fe}-\mathrm{Al}$ 合 金層を形成させるものであるが，工業的に実用化されている方 法では表面 $\mathrm{Al}$ 濃度が 45 mass\%以上 ${ }^{(11)}$ に達し, 表面の高 $\mathrm{Al}$ 濃度化は避けられない。拡散剤中にフェロアルミ粉末と八ロゲ ン化物を配合したものを用いた場合，フェロアルミの $\mathrm{Al}$ 組成 と合金層表面の $\mathrm{Al}$ 濃度が良く一致することも報告されている が(12)，低 $\mathrm{Al}$ 濃度の合金層の形成については報告されていな い.

本研究では, $\mathrm{Al}$ を 8 18 mass\%含有する低 $\mathrm{Al}$ 合金層を形 成させるために, 粉末パック法の拡散剤として $\mathrm{Al}_{2} \mathrm{O}_{3}$ 粉末と $\mathrm{Mg}$ 粉末の混合物を用いて, 鉄筋コンクリート用鋼材の $\mathrm{Al}$ 拡 散被覆を試みた。表面 $\mathrm{Al}$ 濃度は，拡散剤中 $\mathrm{Al}$ の鋼材表面へ の供給速度と，母材中への $\mathrm{Al}$ の拡散速度の相対比に依存する から ${ }^{(13)}$ ，拡散剤にハロゲン化物を添加した場合は，拡散剂か らの $\mathrm{Al}$ の供給が母材中の拡散を上回り, 表面が高 $\mathrm{Al}$ 濃度に なってしまうため, 本研究では八ロゲン化物を添加しない方法 を採用した。また，還元剤の $\mathrm{Mg}$ は，鋼中にほとんど溶解し ないことから，還元により生成した $\mathrm{Al}$ のみが拡散した $\mathrm{Fe}-\mathrm{Al}$ 合金層が形成され，さらに拡散斉の配合割合，処理温度，時間 等を調整すれば低 $\mathrm{Al}$ 濃度の合金層の形成が可能な筈である. 最初に低 $\mathrm{Al}$ 合金層を得るための処理条件を調査し，次に得ら れた合金層のアノード分極特性ならびに合金層が母材の機械的 特性に及ぼす影響について検討を行い，最後にこの種の拡散剤 を用いた方法による合金層の形成機構について考察した。 た，低 $\mathrm{Al}-\mathrm{Si}$ 合金層の形成を図るために, $\mathrm{Al}_{2} \mathrm{O}_{3}$ 粉末と $\mathrm{Mg}$ 粉 末の混合物に $\mathrm{SiO}_{2}$ 粉末を添加した拡散剂を用いた処理を行 い，その合金層のアノード分極特性についても調べた。

\section{II. 実 験 方 法}

試験片は鉄筋コンクリート用棒鋼鋼材 (JIS : SD30B, 0.23 mass\%C， 0.24 mass\% $\mathrm{Si}, \quad 1.00$ mass\% $\mathrm{Mn}, 0.020$ mass\%P, $0.016 \mathrm{mass} \% \mathrm{~S}$ ) であり, $3 \mathrm{~mm} \times 17 \mathrm{~mm} \times 35 \mathrm{~mm}$ の板状に切 り出した後, 耐水研磨紙で表面を\#600に仕上げたものを用い た. 拡散剂には, 平均粒径が $4 \mu \mathrm{m}$ の $\alpha \mathrm{Al}_{2} \mathrm{O}_{3}$ 粉末と平均粒径 が $75 \mu \mathrm{m}$ 以下の $\mathrm{Mg}$ 粉末を用い，また $\mathrm{Si}$ を合金化させる場合 には平均粒径が $25 \mu \mathrm{m}$ の $\mathrm{SiO}_{2}$ 粉末を用いた。な拉， $\alpha \mathrm{Al}_{2} \mathrm{O}_{3}$ 粉末と $\mathrm{SiO}_{2}$ 粉末は特級試薬を用いた。

拡散被覆処理は, 最初に所定の割合になるように配合した $24 \mathrm{~g}$ の拡散剂を外径 $25 \mathrm{~mm} \times$ 内径 $20 \mathrm{~mm} \times$ 長さ $120 \mathrm{~mm}$ の高 純度アルミナ質タンマン管に充填し, 試験片をその中央部に埋 め込んだ. 次に，これを外径 $46 \mathrm{~mm} \times$ 内径 $40 \mathrm{~mm} \times$ 長さ 400 $\mathrm{mm}$ の透明石英管内に挿入し, 管内を $\mathrm{Ar}$ ガスで十分置換後, 1173 1373 K 間の所定温度に保持された電気炉で 0.45〜 5.4 $\mathrm{ks}$ 加熱した. その後, 透明石英管を電気师から抜き出し, 室 温まで泠却した。な抏，処理温度はタンマン管の側方に挿入し た熱電対により検出した.

処理後の試験片は, 蛍光 $\mathrm{X}$ 線による表面 $\mathrm{Al}$ 濃度の定量, 合 金層断面の光学顕微鏡観察ならびに EPMA による $\mathrm{Al}$ の線分 析を行った.

また，コンクリート中の高アルカリ環境下に执ける合金層の
耐塩性を評価するため, $298 \mathrm{~K} に$ 保持した 0.8 mass $\% \mathrm{NaCl}$ を 含む $\mathrm{pH} 12$ の $\mathrm{Ca}(\mathrm{OH})_{2}$ 水溶液中にてアノード分極測定を行っ た. その際，飽和カロメル電極 $(\mathrm{SCE})$ を参照電極として用い， 電位走查法により測定した. 掃引度は $50 \mathrm{mV} / \mathrm{min}^{-1}$ で貴側に 印加した.

さらに，引張試験および曲げ試験を行い，合金層の形成と加 熱による母材の機械的性質の变化括よび合金層の亀裂発生状況 を調查した。引張試験片は, 全長 $100 \mathrm{~mm}$, 平行部 $\phi 6$ $\mathrm{mm} \times 60 \mathrm{~mm}$, チャック部 $\phi 10 \mathrm{~mm} \times 20 \mathrm{~mm}$, 曲げ試験片は $\phi 6 \mathrm{~mm} \times 100 \mathrm{~mm}$ の円柱に仕上げ, 試料に所定の処理を施した 後, 試験に供した. 引張試験にはアムスラー型試験機を用い引 張速度は $10 \mathrm{~mm} / \mathrm{min}$ とした. 曲げ試験は巻付け曲げ試験方式 で行った. 加工度は曲げ半径/試験片半径 $(R / r)$ 比で3.33から 0.67 をで段階的に変化させ, 各 $R / r$ 比に打敄亀裂の発生状 況を SEMにより観察した.

\section{III. 結果および考察}

\section{1. 拡散剂組成, 処理温度および時間の影響}

処理温度および時間を $1273 \mathrm{~K}, 2.7 \mathrm{ks}$ 一定とし, 合金層形 成に及ぼす拡散剂の $\mathrm{Mg}$ 配合量の影響について調べた. Fig. 1 に合金層断面の EPMA による線分析結果を示す．いずれの配 合組成の拡散剤に抏いても, $\mathrm{Al}$ 濃度は, 表面から内部に向か って連続的に減少した。 また，表面 $\mathrm{Al}$ 濃度および合金層厚さ は $\mathrm{Mg}$ 配合量とともに増大し，5〜30 mass\% $\mathrm{Mg}$ に扣いて表 面 $\mathrm{Al}$ 濃度が 8〜18 mass\%に相当する合金層が得られた。

Fig. 1 の試験片の合金層表面についてX線回折を行った結 果, 表面 $\mathrm{Al}$ 濃度が 10 mass \% 前後の場合， $\alpha \mathrm{Fe}$ 相のみが同定 され，12 13 mass\% $\mathrm{Al}$ では $\mathrm{Fe}_{3} \mathrm{Al}$ ，さらに 17 mass\% $\mathrm{Al}$ に まで増大すると $\mathrm{FeAl}$ が同定された。な拉，この 17 mass\% $\mathrm{Al}$ 合金層の表面には空孔が観察された。

次に，拡散剤の配合割合を一定にし，表面 $\mathrm{Al}$ 濃度に及ぼす 処理温度执よび時間の影響について調べた。Fig. 2 は 20 mass\% $\mathrm{Mg}$ 配合の場合に拈ける表面 $\mathrm{Al}$ 濃度と処理時間の関係

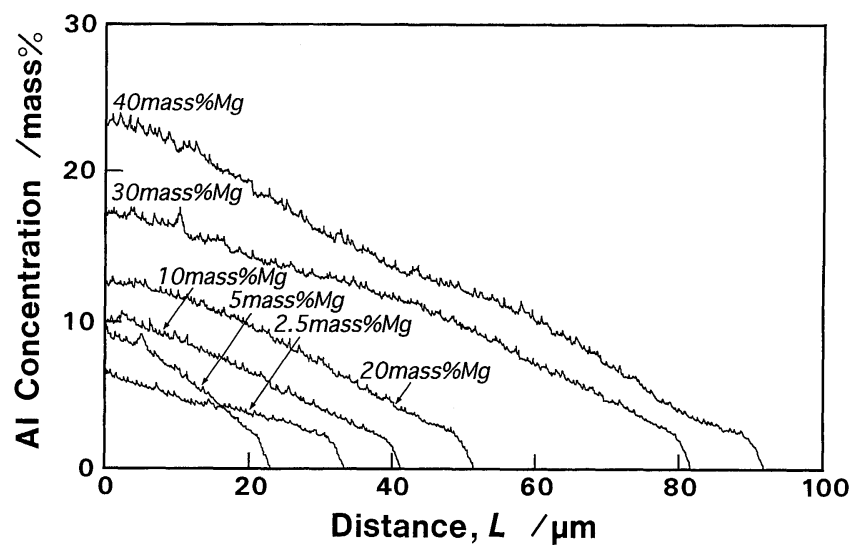

Fig. 1 Results of line-analysis by EPMA across the cross-sections of the alloyed layers formed by treatment at $1273 \mathrm{~K}$ for $2.7 \mathrm{ks}$ using powder mixtures of various compositions. 


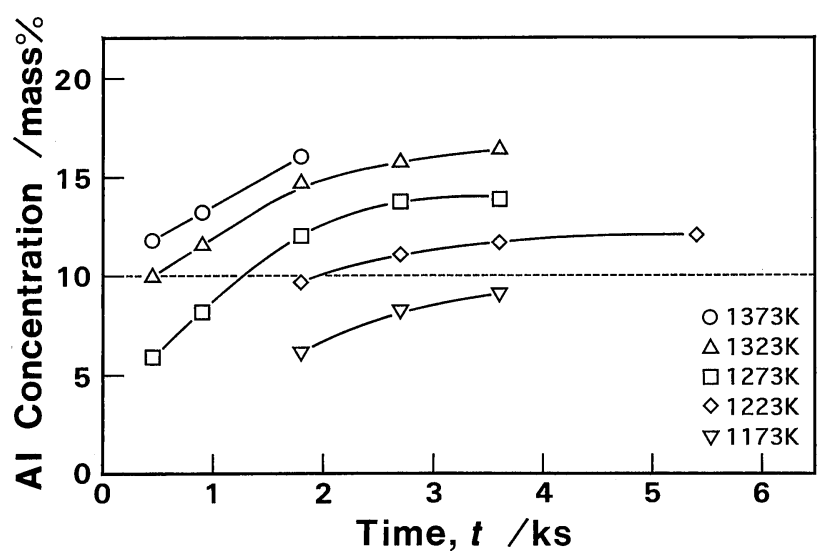

Fig. 2 Effect of the treating time on the surface $\mathrm{Al}$ concentration of the alloyed layer formed by treatment at various temperatures with the powder mixture containing 20 mass\% $\%$ g.

を示す．時間の経過とともに表面 $\mathrm{Al}$ 濃度は緩やかに増加し， 長時間後には飽和した。 また, 高温ほど表面 $\mathrm{Al}$ 濃度の増加は 速やかで，比較的短時間で 10 mass\% $\%$ V に達した。

Fig. 3 は 10 mass\%Mg-90 mass $\% \mathrm{Al}_{2} \mathrm{O}_{3}$ の拡散剂に $\mathrm{SiO}_{2}$ を 1〜10 mass\%添加した場合の表面 $\mathrm{Al}$ 就よび $\mathrm{Si}$ 濃度と合金層 厚さの変化を示す.な拈, 処理条件は $\mathrm{SiO}_{2}$ 無添加の場合に約 10 mass\% $\mathrm{Al}$ の表面 $\mathrm{Al}$ 濃度が得られた $1273 \mathrm{~K}, 2.7 \mathrm{ks}$ であ る. $\mathrm{SiO}_{2}$ 添加量の増加とともに表面 $\mathrm{Al}$ 濃度は大幅に低下し, また合金層厚さも減少した．これに対して，表面 $\mathrm{Si}$ 濃度は 5 mass $\% \mathrm{SiO}_{2}$ まで上昇し， 3.5 mass\%の最大值を示した後，さ らに多量に $\mathrm{SiO}_{2}$ を添加すると低下した。

\section{2. アノード分極特性}

Fig. 4 は種々の配合組成の拡散剂を用いて $1273 \mathrm{~K} に て 2.7$ $\mathrm{ks}$ 処理した試験片のアノード分極曲線を示す. 10 mass\% $\% \mathrm{Mg}$ 配合の拡散剤を用いて得られた表面 $\mathrm{Al}$ 濃度が約 10 mass\%の

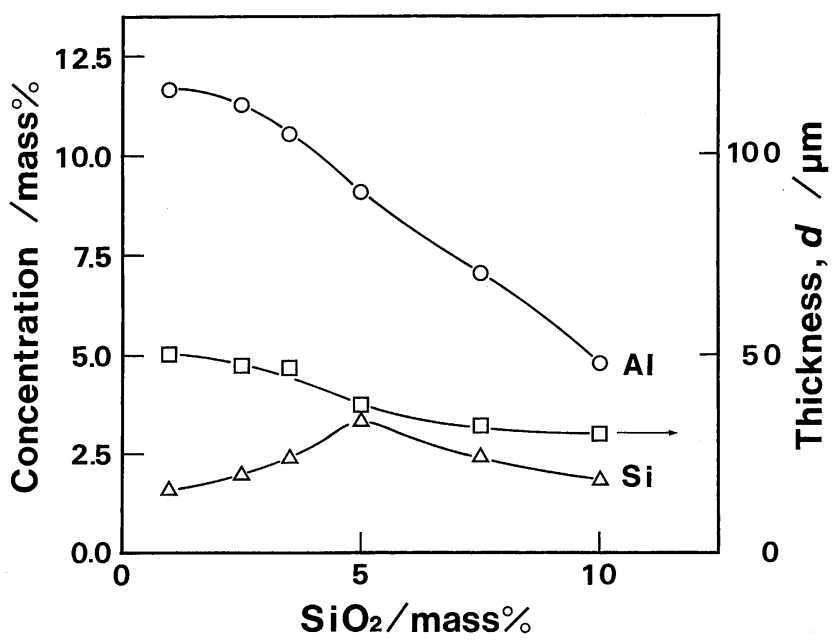

Fig. 3 Effect of the amount of added $\mathrm{SiO}_{2}$ on the surface $\mathrm{Al}$ and $\mathrm{Si}$ concentration of the alloyed layer formed by treatment at $1273 \mathrm{~K}$ for $2.7 \mathrm{ks}$ using the powder mixture consisting of 10 mass $\% \mathrm{Mg}$ and 90 mass $\% \mathrm{Al}_{2} \mathrm{O}_{3}$.

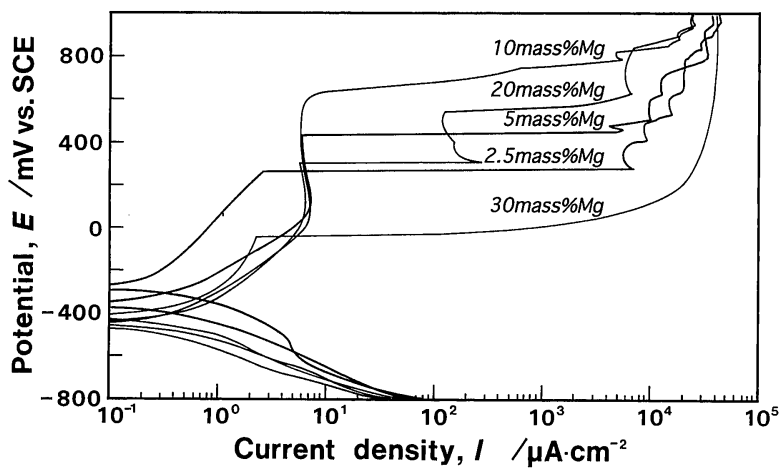

Fig. 4 Anodic polarization curves of the low-Al alloyed layers treated at $1273 \mathrm{~K}$ for $2.7 \mathrm{ks}$ using powder mixture of various compositions.

試験片は, 腐食電位が- $430 \mathrm{mV}$ で, その後, 電位の上昇に伴 、電流密度は緩やかに増大し, $0 \mathrm{mV}$ 前後で不働態を形成し, $+600 \mathrm{mV}$ 付近の孔食電位まで不働態維持電流密度は $7 \mu \mathrm{A} /$ $\mathrm{cm}^{2}$ を保持した。これに対して, 表面 $\mathrm{Al}$ 濃度がさらに高くな ったり，あるいは低下すると，腐食電位は増大し，また孔食電 位は卑側に移動した。な抏, 表面 $\mathrm{Al}$ 濃度が 10 mass\%前後で あれば，処理条件が異なってもいずれも良好な耐食性を示し た。例えば， 20 mass\% $\mathrm{Mg}$ 配合の拡散剤を用いて $1323 \mathrm{~K}$ に て $0.45 \mathrm{ks}$ 処理した試験片は, Fig. 2 から表面 $\mathrm{Al}$ 濃度が 10.0 mass\%であるため, 孔食電位は $+600 \mathrm{mV}$ に達した。

Fig. 5 は 10 mass $\% \mathrm{Mg}-90$ mass $\% \mathrm{Al}_{2} \mathrm{O}_{3}$ の混合物に $\mathrm{SiO}_{2}$ を 添加した拡散剤を用いて $1273 \mathrm{~K} に て 2.7 \mathrm{ks}$ 処理した試験片の アノード分極曲線を示す. $\mathrm{SiO}_{2}$ を 10 mass\%添加した場合は， 表面 $\mathrm{Al}$ 濃度が 4.8 mass\%, Si 濃度が 1.8 mass\%の試験片が得

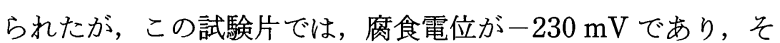
の後, 電流密度は緩やかに増加し, $+620 \mathrm{mV}$ 付近の孔食電位 まで不働態維持電流密度は $1 \mu \mathrm{A} / \mathrm{cm}^{2}$ を超えなかった。これに 対して, 表面 $\mathrm{Al}$ 扔よび $\mathrm{Si}$ 濃度がさらに高くなると, 腐食電位 は低下するが，不働態維持電流密度は増大した。

未処理の母材，アルミニウム拉よびステンレス鋼(SUS304) についてアノード分極測定を行い，低 $\mathrm{Al}$ 合金層扣よび低 $\mathrm{Al}-$

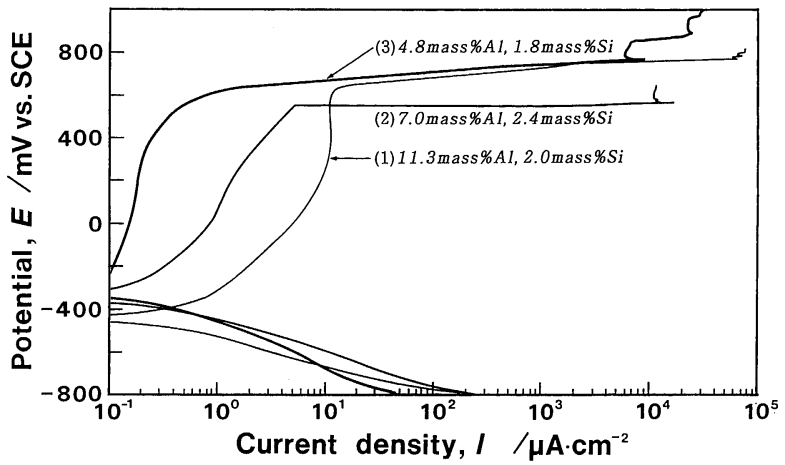

Fig. 5 Anodic polarization curves of the low Al-Si alloyed layers formed by treatment at $1273 \mathrm{~K}$ for $2.7 \mathrm{ks}$ using powder mixture containing (1) 2.5 mass $\% \mathrm{SiO}_{2}$, (2) 7.5 mass $\% \mathrm{SiO}_{2}$ and (3) 10 mass $\% \mathrm{SiO}_{2}$. 
$\mathrm{Si}$ 合金層を形成させた処理材と比較した結果をFig. 6 亿示 す。な扣，低 $\mathrm{Al}$ 合金層の試験片は Fig. 4 の 10 mass\% Mg90 mass $\% \mathrm{Al}_{2} \mathrm{O}_{3}$ の拡散剤を用いたもの，低 $\mathrm{Al}-\mathrm{Si}$ 合金層の試 験片は Fig. 5 の 10 mass\% $\%$ g- 90 mass $\% \mathrm{Al}_{2} \mathrm{O}_{3}$ の混合物に $10 \mathrm{mass} \% \mathrm{SiO}_{2}$ を添加した拡散剤を用いたものである。いず れの処理材も母材と比べると孔食電位が貴側に著しく増大し た.また, ステンレス鋼と比べると孔食電位はほぼ同じ值を示 し, 不働態維持電流密度は低 $\mathrm{Al}$ 合金層の試験片ではわずかに 高いが，低 Al-Si 合金層では著しく低い。

\section{3. 機械的特性の評価}

Fig. 4 亿打いて良好なアノード分極特性を示した 10 mass $\% \mathrm{Mg}$ の拡散剤を用い, $1273 \mathrm{~K} に て 2.7 \mathrm{ks}$ 処理した処理 材と, それと同じ熱履歷を与えた母材(焼鈍材) 拉よび熱処理し ない母材の機械的性質を比較した。 その結果を Table 1 亿示 す. 処理材は加熱による結晶粒の粗大化のために母材に比べて 降伏点と引張強さはわずかながら低下したが, 焼鈍材と比べて 降伏点, 引張強さ拈よび伸びはいずれもほとんど同じであっ た.したがって，合金層の形成によって機械的性質は低下しな

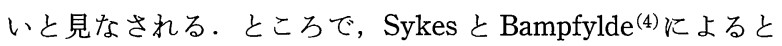
$1023 \mathrm{~K}$ にて $3.6 \mathrm{ks}$ 焼鈍後の $7.33 \mathrm{mass} \% \mathrm{Al}$ 鋼の降伏点, 引張 強さ拉よび伸びはそれぞれ 457.2 MPa, 515.9 MPa 㧊よび 5.5\%であり， Al 含有量がさらに 10.25 mass\%から 11.16 mass\%Al に増加すると, 降伏点および伸びのデータは測定さ れていないが, 引張強さは反対に $276.4 \mathrm{MPa} か 251.76$ MPa に減少するとされている. Table 1 の処理材の表面 $\mathrm{Al}$ 濃 度は, Fig. 1 に示されるよらに約 10 mass\%であるが，このよ 万に表面 $\mathrm{Al}$ 濃度が比較的高いにもかかわらず，機械的性質が

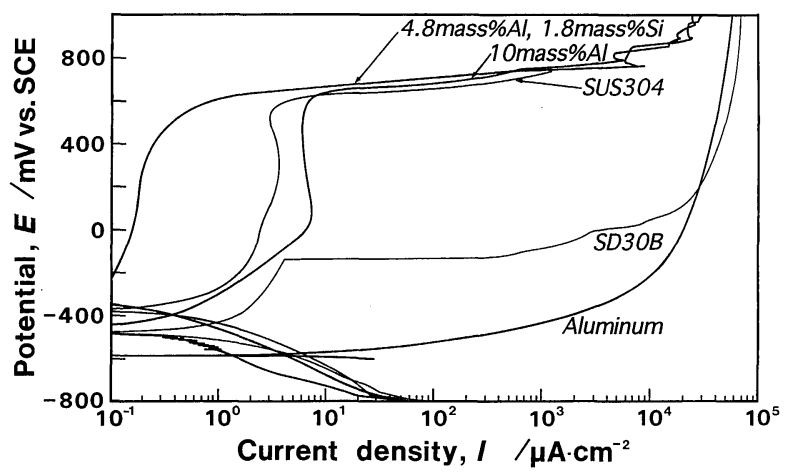

Fig. 6 Comparison with the polarization curves of various materials.
ほとんど低下しない原因は，合金層内部に向かって緩やかな $\mathrm{Al}$ の濃度勾配を有し, 加えて引張試験片の平行部の断面積に 占める合金層の割合が $2.6 \%$ と非常に小さいためと考えられる.

次に，処理材について合金層と母材との密着性を調べるため 曲げ試験を行い，湾曲部の外周部の亀裂の発生状況を SEM に より観察した．処理材は 10 mass\% $\mathrm{Mg}$ の拡散剤を用い $\alpha \mathrm{Fe}$ の 合金層を形成させたものと, 30 mass\% $\mathrm{Mg}$ の拡散剂を用いて $\mathrm{FeAl}$ の合金層を形成させたものであり，いずれも $1273 \mathrm{~K} に$ て $2.7 \mathrm{ks}$ 拡散処理を行った. その結果, Fig. 7 に示すように $\alpha \mathrm{Fe}$ の合金層では, 本実験で設定した最大の加工度である $R / r$ 值 $=0.67$ まで亀裂の発生は見られず，母材との優れた密着性を 示した。一方, $\mathrm{FeAl}$ の合金層では, $\mathrm{FeAl}$ が脆弱で, しかも 合金層に空隙も存在するため, $R / r=3.33$ の低い加工度で亀裂 が発生し, さらに $R / r$ 值の増加とともに亀裂の幅が増大した。

\section{4. 低 $\mathrm{Al}$ 合金層の形成機構}

低 $\mathrm{Al}$ 合金層の形成機構を明らかにするため 2,3 の検討実験 を行った. Fig. 8 は $1273 \mathrm{~K}$ にて $2.7 \mathrm{ks}$ 処理後の拡散剂の $\mathrm{X}$ 線回折結果を示す. $\mathrm{Mg}$ 配合量の増加とともに $\alpha \mathrm{Al}_{2} \mathrm{O}_{3}$ 扣よび $\mathrm{MgAl}_{2} \mathrm{O}_{4}$ の回折強度は低下し, 反対に $\mathrm{MgO}$ 拈よび $\mathrm{Al}$ の回折 強度は増大した。また， 40 mass\% $\mathrm{Mg}$ 配合では $\mathrm{Al}$ の他に $\mathrm{Al}_{3} \mathrm{Mg}_{2}$ の生成が確認された. $\mathrm{Al}$ の格子定数は, $\mathrm{Mg}$ 配合量が 10, 20, 30执よび 40 mass\% と増加するに伴い， 0.4050, 0.4061, 0.4069 および $0.4077 \mathrm{~nm}$ と増大した。したがって, $\mathrm{Al}_{2} \mathrm{O}_{3}$ の

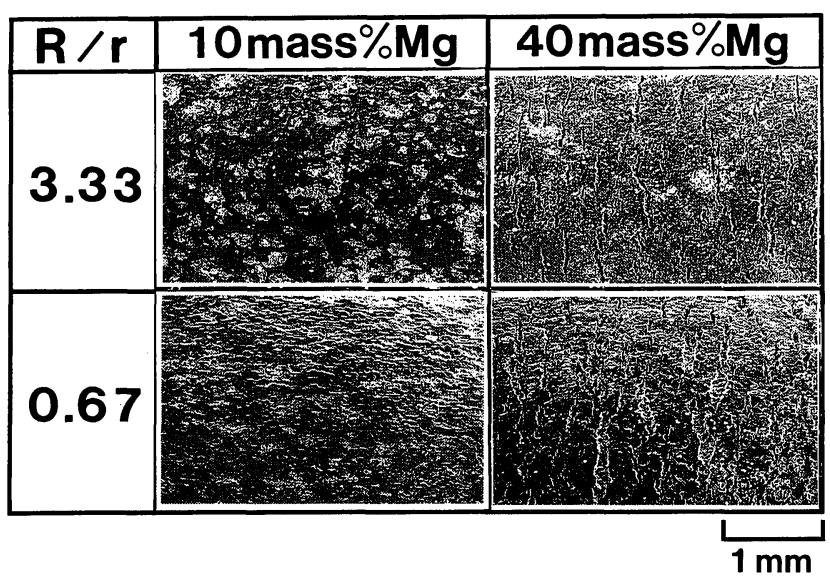

Fig. 7 SEM photographs of the bent portion of the specimens formed by treatment at $1273 \mathrm{~K}$ for $2.7 \mathrm{ks}$ using the powder mixture containing 10 mass $\% \mathrm{Mg}$ and 40 mass $\%$ $\mathrm{Mg}$.

Table 1 Results of comparing the mechanical properties of the specimen formed by treatment at $1273 \mathrm{~K}$ for $2.7 \mathrm{ks}$ using the powder mixture containing 10 mass $\% \mathrm{Mg}$, parent steel annealed at the same condition and untreated parent steel.

\begin{tabular}{|c|c|c|c|c|c|c|}
\hline \multirow{2}{*}{ Specimen } & \multicolumn{3}{|c|}{ Treating conditions } & \multirow{2}{*}{$\begin{array}{c}\text { Yield } \\
\text { point/MPa }\end{array}$} & \multirow{2}{*}{$\begin{array}{c}\text { Tensile } \\
\text { strength/MPa }\end{array}$} & \multirow{2}{*}{ Elongation/\% } \\
\hline & Powder mixture/mass $\%$ & Temp./K & Time/ks & & & \\
\hline Treated steel & $\begin{array}{l}10 \% \mathrm{Mg}-90 \% \mathrm{Al}_{2} \mathrm{O}_{3} \\
10 \% \mathrm{Mg}-90 \% \mathrm{Al}_{2} \mathrm{O}_{3}\end{array}$ & $\begin{array}{l}1273 \\
1273\end{array}$ & $\begin{array}{l}1.8 \\
2.7\end{array}$ & $\begin{array}{l}325.3 \\
312.3 \\
\end{array}$ & $\begin{array}{l}533.1 \\
537.0\end{array}$ & $\begin{array}{l}26.3 \\
27.3\end{array}$ \\
\hline Annealed steel & & $\begin{array}{l}1273 \\
1273\end{array}$ & $\begin{array}{l}1.8 \\
2.7\end{array}$ & $\begin{array}{l}313.6 \\
311.6\end{array}$ & $\begin{array}{l}524.3 \\
527.2\end{array}$ & $\begin{array}{l}26.7 \\
28.0\end{array}$ \\
\hline Parent steel & & & & 396.9 & 544.9 & 26.3 \\
\hline
\end{tabular}


$\mathrm{Mg}$ 還元により生成する $\mathrm{Al}$ の量およびその $\mathrm{Mg}$ 濃度は $\mathrm{Mg}$ 配 合量の増加とともに上昇し， 40 mass $\% \mathrm{Mg}$ 配合では $\mathrm{Al}$ 中の

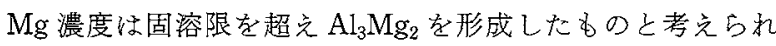
る.

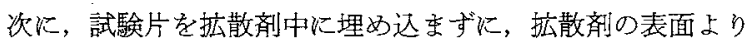
$5 \mathrm{~mm}$ 上万に保持した力法により合金層の形成を図った。 10 mass\% $\%$ g の拡散剂を用い，1273 K飞て $2.7 \mathrm{ks}$ 処理した合金 層表面の SEM 像をFig. 9 亿示す．白色を呈する多数の粒子 の付着が観察され，EPMA に上る Mg-k $k x ， \mathrm{O}-k \alpha$ の分析の結果, $\mathrm{Mg}$ 就よびOの濃化が見られたので，MgO粒子の付着である ことが確認された。この試験片の表面の Al 濃度は 2.8 mass\% で，試験片を拡散剤中に埋め込んだ場合の約 10 mass\%上りは かなり低いが，合金層の形成が認められた。したがって，何ら かの蒸気種が合金層の形成に奇与していることが推定される。 なお，試験片を拡散剤中に埋め込んだ方法では，試験片表面へ の $\mathrm{MgO}$ の付着はほとんど見られなかった。

そこで，以上の実駼結果から合金層は次のような機構により 形成されるものと考光られる。最初に式(1)の反応机上り $\mathrm{Al}_{2} \mathrm{O}_{3}$ が一部還元されて $\mathrm{Al}_{2} \mathrm{O}$ 蒸気を生成与る。 な持，反応(1) 以降の標準自由エネルギー変化 $\left(\Delta G^{\circ}\right)$ は Turkdogan ${ }^{(14)}$ の収録 データから求めた。

$$
\begin{aligned}
& 3 \mathrm{Al}_{2} \mathrm{O}_{3}(\mathrm{~s})+2 \mathrm{Mg}(\mathrm{l})=\mathrm{Al}_{2} \mathrm{O}(\mathrm{g})+2 \mathrm{MgAl}_{2} \mathrm{O}_{4}(\mathrm{~s}) \\
& \Delta G^{\circ} / \mathrm{J}=225600-145.81 T
\end{aligned}
$$

$\mathrm{Mg}$ の活量が 1 の場合と, A 2 合金化して0.05に低下した 場合の $\mathrm{Al}_{2} \mathrm{O}$ の平衡蒸気圧を求めると Fig. 10 のよらにり, 処理温度範团ではかなり揮発することがわかる．次に $\mathrm{Al}_{2} \mathrm{O}$ は 気相を介して到達し，式（3）にしたがって $\mathrm{Mg}$ 蒸気によって 還元さ祅，鋼中に固溶する。

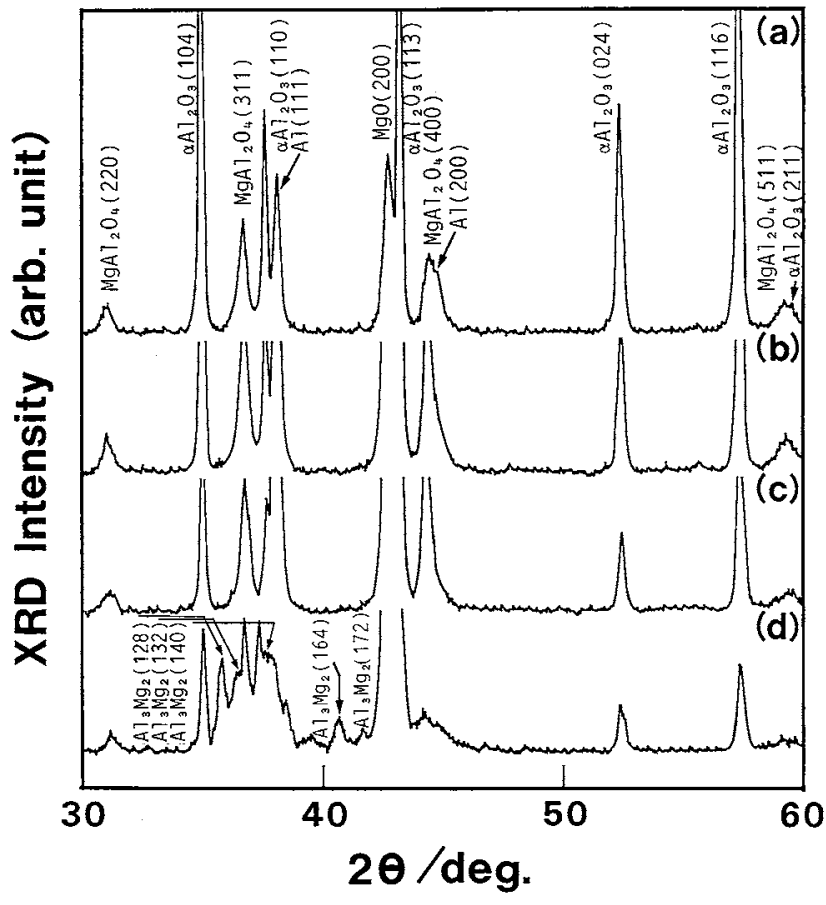

Fig. 8 X-ray diffraction patterns of the powder mixtures after treatment for $2.7 \mathrm{ks}$ at $1273 \mathrm{~K}$ : (a) 10 mass $\% \mathrm{Mg}$, (b) 20 mass $\% \mathrm{Mg}$, (c) 30 mass $\% \mathrm{Mg}$, (d) 40 mass $\% \mathrm{Mg}$.

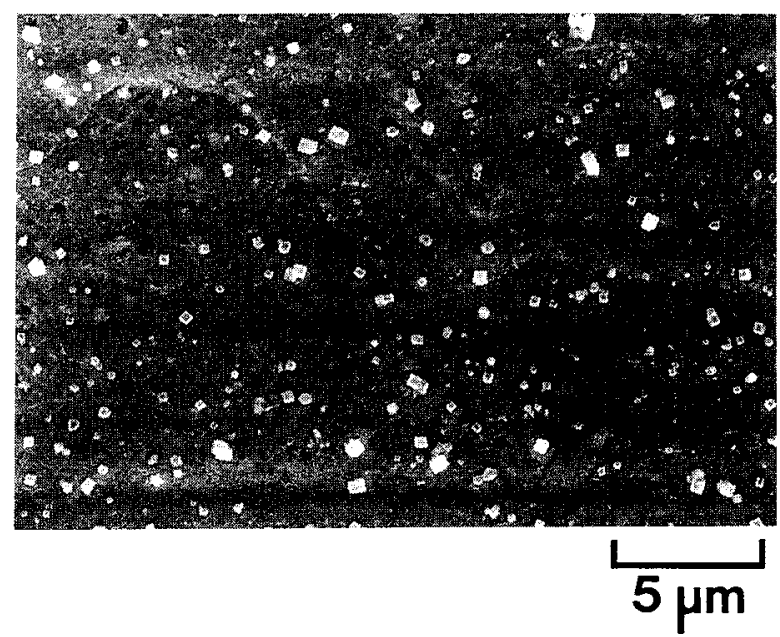

Fig. 9 SEM photograph of the surface of specimen formed by treatment at $1273 \mathrm{~K}$ for $2.7 \mathrm{ks}$ in no contact of the specimen with the powder mixture of 10 mass $\% \mathrm{Mg}$.

$$
\begin{aligned}
& \mathrm{Al}_{2} \mathrm{O}(\mathrm{g})+\mathrm{Mg}(\mathrm{g})=\mathrm{Al}(\mathrm{l})+1 / 2 \mathrm{MgO}(\mathrm{s}) \\
& \Delta G^{\circ} / \mathrm{J}=-558900+253.423 \mathrm{~T}
\end{aligned}
$$

還元生成物の $\mathrm{MgO}$ は, 試験片を拡散風と接触させなかった 場合は試験片の表面に生成するが，試験片を拡散斉中に埋め込 んだ場合は，試験片に接触している挔散剤中の $\mathrm{Al}_{2} \mathrm{O}_{3}$ と反応 ᄂ, $\mathrm{MgAl}_{2} \mathrm{O}_{4}$ を形成するため, 試験片の表面に汪とんど付着 しなかったものと考光ら机る。ところで，Fig. 2 に扎いて各温 度とも一定温度で処理した場合, 表面 $\mathrm{Al}$ 濃度が長時間後に飽 和した理由として，還元により生成した $\mathrm{A} 1$ との合金化により $\mathrm{Mg}$ の活量が低下するため式 (1)さらには式 (3)の反応が進行 しなくなるすのと考克られる。また，Mg配合量を減ずると表 面 $\mathrm{Al}$ 濃度が低下寸ることる同様に説明できる。

\section{5. 低 Al-Si 合金層の形成機構}

10 mass $\% \mathrm{Mg}-90$ mass $\% \mathrm{Al}_{2} \mathrm{O}_{3}$ の 混合物に $\mathrm{SiO}_{2}$ ～ 12

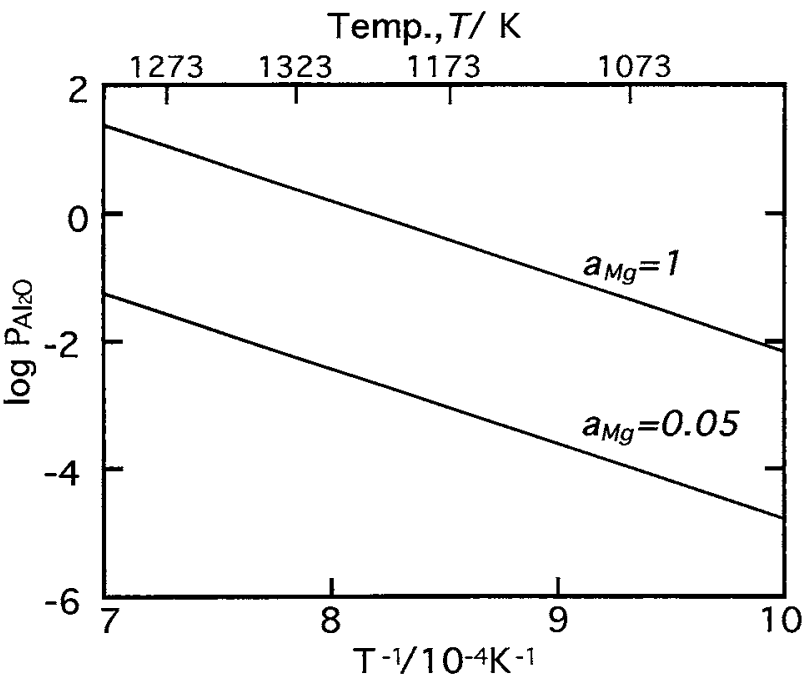

Fig. 10 Equilibrium vapor pressure of $\mathrm{Al}_{2} \mathrm{O}$ when the activity of $\mathrm{Mg}$ is 1 and reduced to 0.05 as a result of alloying of $\mathrm{Mg}$ with Al. 


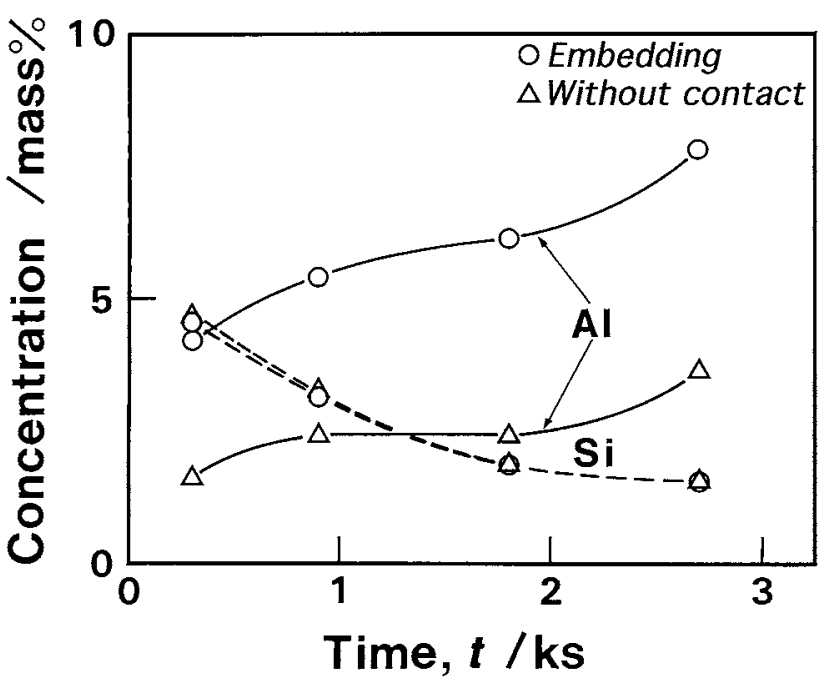

Fig. 11 Effect of the treating time on the surface $\mathrm{Al}$ and $\mathrm{Si}$ concentration of alloyed layer formed in no contact of the specimen with the powder mixture.

mass\%添加した拡散剂を用い， $1273 \mathrm{~K} に て 2.7 \mathrm{ks}$ の処理を行 い,この処理後の搪散剂の X 線回折を行った。その結果, す べての搪散剤から未反応の $\alpha \mathrm{Al}_{2} \mathrm{O}_{3}$ の他，反応生成物として $\mathrm{Al}, \mathrm{MgO}, \mathrm{MgAl}_{2} \mathrm{O}_{4}, \mathrm{MgAl}_{2} \mathrm{Si}_{3} \mathrm{O}_{10}$ が同定された。なお， $\mathrm{MgAl}_{2} \mathrm{Si}_{3} \mathrm{O}_{10}$ の回折強度は $\mathrm{SiO}_{2}$ 添加量の増加とともに増大し た.

また，試験片を昖散剤中に理め込まずに，拡散昘の表面より $5 \mathrm{~mm}$ 上万に保持した力法により合金層の形成を図った。

Fig. 11 はこの実験に和ける表面 $\mathrm{Al}$ 扣よび Si 濃度の経時变化 を，試験片を拡散剤中に埋め込んだ場合と比較して示す、いず れの方法の場合も処理時間ととも几表面 $\mathrm{Al}$ 濃度は増大し, 反 対に表面 $\mathrm{Si}$ 濃度は低下した。

以上の実験結果から低 $\mathrm{Al}-\mathrm{Si}$ 合金層の形成機構は次のように 考完られる。李ず式(1)と式(5)の反㐫により $\mathrm{Al}_{2} \mathrm{O}_{3}$ 扰よび $\mathrm{SiO}_{2}$ が還元されてとれぞれ $\mathrm{Al}_{2} \mathrm{O}$ 扣よび $\mathrm{SiO}$ 蒸気を生成する。 次いで， $\mathrm{Al}_{2} \mathrm{O}$ は式(3)， $\mathrm{SiO}$ は次の式(7)の反応に上り $\mathrm{Mg}$ 蒸気によって還元され，鋼中に固溶寸るるのと推定される。た だし反応(1)上り反応(5)の方が $\Delta G^{\circ}$ 值が小さいため, 反応初 期では反応(5)が先行するものと考兄られ，事実，表面 Si 濃度 はとくに試験片を桩散剤之接触させない場合，A1濃度を大幅 に上回った。 しかし，妈理時間が長くなると， $\mathrm{SiO}_{2}$ は $\mathrm{Al}_{2} \mathrm{O}_{3}$ 频よび還元生成物の $\mathrm{MgO}$ との応により複酸化物 $\left(\mathrm{MgAl}_{2} \mathrm{Si}_{3} \mathrm{O}_{10}\right)$ を形成し安定化されるため, $\mathrm{SiO}$ 蒸気はほとん ぞ生成しなくなる。この段階では反応初期に鋼中に固溶した Si は時間の経過とともに内部に拡散し，昰た後から固溶して くる $\mathrm{Al}$ とよる希釈効果すあって，表面 $\mathrm{Si}$ 濃度は長時間ほど低 下する象のと考完られる。

$$
\begin{aligned}
& \mathrm{SiO}_{2}(\mathrm{~s})+\mathrm{Mg}(\mathrm{l})=\mathrm{SiO}(\mathrm{g})+\mathrm{MgO}(\mathrm{s}) \\
& \Delta G^{\circ} / \mathrm{J}=193010-140.96 T \\
& \mathrm{SiO}(\mathrm{g})+\mathrm{Mg}(\mathrm{g})=\mathrm{Si}(\mathrm{s})+\mathrm{MgO}(\mathrm{s}) \\
& \Delta G^{\circ} / \mathrm{J}=-625420+286.56 T
\end{aligned}
$$

N. 結論

本研究では，鉄筋コンクリート用鋼材の耐塩性の向上を計る ため， $\mathrm{Al}_{2} \mathrm{O}_{3}$ 粉末と $\mathrm{Mg}$ 粉末の混合物を拡散剂として用いた粉 末パック法による低A1 合金化処理を試みた。

得られた結果を以下に要的する。

（1）表面 $\mathrm{Al}$ 濃度々合金層厚さは，処理温度，処理時間和よ び拡散剤の $\mathrm{Mg}$ 配合量の堌加とともに増大した。

(2) 10 mass $\% \mathrm{Mg}-90$ mass $\% \mathrm{Al}_{2} \mathrm{O}_{3}$ の混合物飞 $\mathrm{SiO}_{2}$ を添加 した拡散風を用いた場合, $\mathrm{SiO}_{2}$ 添加量の増加とともに表面 $\mathrm{AI}$ 濃度と合金層厚さは減少し，一方，表面 $\mathrm{Si}$ 濃度は 5 mass\%以 て最大值を示した。

（3）表面 $\mathrm{Al}$ 濃度が 10 mass\%付近の合金層はアノード分極 測定の結果, 腐食電位が $-430 \mathrm{mV}$, 不働態維持電流密度が 7 $\mu \mathrm{A} / \mathrm{cm}^{2}$ 前後, 孔食電位は $+600 \mathrm{mV}$ で良好な耐食性を示し た。これに対して，表面 $\mathrm{Al}$ 濃度がさらに増加おるいは低下す ると腐食電位は上昇し，孔食電位は低下した。

（4）表面 Al 濃度が 4.8 mass \%, Si 濃度が 1.8 mass\%の低 $\mathrm{Al}-\mathrm{Si}$ 合金層の場合，腐食電位は－230 mV，不働熊維持電流密 度は $1 \mu \mathrm{A} / \mathrm{cm}^{2}$ 以下，孔食電位は $+620 \mathrm{mV}$ 付近であり，不働 態維持電流密度は低 $\mathrm{Al}$ 合金層のすのより低下した。ただし， 表面の Al と Si 濃度がさらに高くなると，腐食電位は低下する が，不働態維持電流密度はむしろ増大した。

(5)引張試験および曲げ試験の結果，約 10 mass\% $\%$ l の合 金層は母材の機械的性質を注とんど低下させず，また母材との 密着性にも優れていることがわかった。

（6）試験片と拡散剂を非接触の状態で加熱しても合金層が形 成された。このことから，合金層は拡散剂中で発生した $\mathrm{Al}_{2} \mathrm{O}$ 扣よび $\mathrm{SiO}$ 蒸気が試験片の表面に括いて $\mathrm{Mg}$ 蒸気により還元 されて形成するものと考察した。

\section{文献}

（1）笠井芳夫：コンクリート工学, 25(1987), 28.

(2) 新井哲三: ニンクリート工学, 25(1987), 34.

(3) C. Dehahanian and C. E. Locke: Corrosion, 38 (1982), 494.

(4) C. Sykes and J. W. Bampfylde: J. Iron and Steel Institute, $100(1934), 389$.

（5）公開特許公報，昭64-79346.

（6）内田幸夫, 服部保德, 広瀬祐輔：日新技報, 60 (1989), 122

(7) R. A. Legault and V. P. Pearson: Corrosion, 34(1978), 344.

(8) T. Johnsson and L. Nordhag: Proc. Interfinish 84, Israel, (1984), 412.

( 9 ) S. B. Agarwal and R. A. Legault: Materials Performance, 22(1983), 19.

(10) S. Denner and Y. W. Kim: Proc. Symp. High-Temp. Prot. Coat. at AIME Meeting, Atlanta, (1982), 233.

（11）吉田 薰, 河上 護：熱処理, 27(1987), 10.

(12) T. H. Wang and L. L. Seigle: Materials Science and Eng., A108(1989), 253.

(13) S. C. Kung and R. A. Rapp: J. Electrochem. Soc., 135 (1988), 731.

(14) E. T. Turkdogan: Physical Chemistry of High Temperature Technology, Academic Press, N. Y., (1980), 5. 